\title{
Öğrenci Merkezli Karma Öğretim Yönteminin Eleştirel Düşünmeye Etkisi
}

\author{
Doç. Dr. Nuriye SEMERCİ \\ Bartın Üniversitesi Eğitim Fak. Eğitim Bilimleri Bölümü Bartın / Türkiye
}

Yrd. Doç. Dr. Bayram ÖZER

Mustafa Kemal Üniversitesi, Eğitim Fakültesi, Tayfur Sökmen Kampüsü Hatay / Türkiye

\section{Özet}

$\mathrm{Bu}$ araştırmanın amacı, "öğrenci merkezli eğitime dayalı olarak geliştirilmiş olan karma öğretim yönteminin Öğretimde Planlama ve Değerlendirme dersinde öğrencilerin eleştirel düşünmelerine etkisini saptamaktır.” Araştırma, deneysel yöntemlerden birisi olan ön test-son test kontrol gruplu modele göre desenlenmiştir. Deneyin yapılacağı deney ve kontrol gruplarının oluşturulması için altı farklı ölçüt üzerinde kümeleme analizi yapılarak sosyal bilgiler öğretmenliği birinci ve ikinci öğretimden 35'er öğrenci gruplara alınmıştır. Deneysel uygulama toplam altı hafta sürmüştür. Veriler, Eleştirel Düşünme Eğilimi Ölçeği (The California Critical Thinking Disposition Inventory - CCTDI) ile toplanmıştır. Deneysel çalışmanın sonucunda öğrencilerin eleştirel düşünme eğilimlerinin arttı̆̆ belirlenmiştir. Öğrencilerin analitiklik, meraklılık ve kendine güven alt ölçeklerinde eleştirel düşünme eğiliminin anlamlı derecede geliştirilemediği anlaşılmıştır. Bu yüzden farklı karma öğretim modellerinde öğrencilerin bu yönlerinin geliştirilmesine yönelik yöntemler seçilmelidir. 
Anahtar Kelimeler: Öğrenci merkezli eğitim; Eleştirel düşünme; Karma yöntem.

\title{
The Effect of Student-Based Mixed Learning Method on Critical Thinking
}

\begin{abstract}
Aim of this research is to determine the effects of combined teaching method which is developed according to student-centered education on critical thinking of students in the Planning and Evaluation Lesson in teaching. This research is designed according to pretest-final test control group model, which is one of the experimental methods. In order to create experimental and control group from social sciences teacher training department first and second education students, 35 students is taken from each groups by carrying out cluster analysis on six different criterion. Experimental application took six weeks. Data were obtained through California Critical Thinking Disposition Inventory (CCTDI). As a result of this experimental study, it is determined that there is an increase in student's tendency of criticizing. On the other hand, it is observed that critical thinking tendency could not be improved meaningfully for student's sub inventories on analytic thinking, curiosity and self-confidence. For this reason, convinient methods needed to improve such aspect of students in different combined teaching model should be selected.
\end{abstract}

Keywords: Student centered education; Critical thinking; Combined teaching method.

\section{Extended Summary}

Student-centered education is an approach which strongly emphasizes that responsibilities and activities of students should have priority instead of the developing lessons (Ingleton, Kiley, Cannon and Rogers, 2005, 3). During planning and carrying out of student centered education according to Prawat (1992, 359-378), at the centre of the 
class, student and teacher have a role together. Mixed teaching method can be defined as using appropriate methods for aims of lesson and content together in different learning levels and in acquiring target behaviors (Sönmez, 2005, s.333).

\section{Purpose}

Aim of this research is to determine the effects of combined teaching method which is developed according to student-centered education on critical thinking of students in the Planning and Evaluation Lesson in teaching. This research is designed according to pretest-final test control group model, which is one of the experimental methods. In order to create experimental and control group from social sciences teacher training department first and second education students, 35 students is taken from each groups by carrying out cluster analysis on six different criterion.

\section{Methods}

The duration of experimental application took six weeks. Groups which consisted of six students are formed. Firstly, lesson begins with cooperative learning, separate and join method. Then, aquarium method and finally brain storming method are used. Data are obtained through the California Critical Thinking Disposition Inventory (CCTDI). The inventory which is adapted to Turkish by Kökdemir (2003) consists of six sub inventory with 51 items. Inventory's internal consistency coefficient (alfa) is 0.88. Data with the SPSS program are analyzed through Levene test, t-test and Wilcoxon signed rank test. 


\section{Results}

The data collected from the research are like that; as experimental and control group pretests are compared, general average at the experimental group is higher than control groups However, any differences could not be found among the two groups according to T-test results $(t=1,87, p>.05)$. There is no meaningful difference through sub inventory either. Thus, it shows that before experimental application the critical thinking of the students of experimental and control groups, is at the same level. Nevertheless, the average of search of the truth, sub inventory is lower in both group than the other sub inventory points. It is observed that there is a meaningful difference between experimental groups CCTDI general pretest and final test point averages $(Z=-2,83$, $\mathrm{p}>$.05). According to these results, it can be said that experimental application has effects on developing critical thinking disposition. Besides, there is no meaningful difference in CCTDI analytic and curiosity sub inventory statistically. Meaningful difference is found out in CCTDI open-minded search for the truth and systematic sub inventory in favor of final test. Meaningful difference is found out $(t=-1,98$, $\mathrm{p}<.05)$ in favor of pretest between self confidence sub inventory pretest and final test average and the point average gained before and later experimental application $(\mathrm{t}=-1,98, \mathrm{p}<.05)$. When the score averages of CCTDI general pre-test and final test of control group, the average increase in final test, however, it is understood that it is not meaningful according to T-test results $(t=1,07, p>.05)$. On the basis of these results, it could be said that the lessons in control group does not cause any improvement in creating a meaningful difference in students' 
critical thinking tendency. In terms of sub inventories, there is no meaningful difference between sub inventories of CCTDI broad-minded, analytic, curiosity, self-confidence, search for truth and systematic. However, in sub inventory of self-confidence score of final test is lower than pretest's score.

When the final test of the groups are compared together with general average of CCTDI, experiment group is higher than general average of control group, according to T-test results $(t=1,88, p>.05)$ and there is not a meaningful difference. As it is checked by sub inventories such as analytic thinking, open-mindedness, curiosity and self-confidence, although average score of experiment group is little higher than control group, there is no available meaningful difference. In sub inventories of search of the truth and systematic,it is determined that there is a meaningful difference for the experiment group.

\section{Discussion}

As a result of research, generally it is determined that experimental study increase student's tendency of criticizing. As it is checked with the six subinventories of CCTDI, though there is no meaningful difference between pre-test and final test scores at the sub inventories of analytic thinking and curiosity. In self confidence sub inventory, there is a meaningful difference in a negative way. Especially, in self confidence sub inventory, it is fairly provoking that there is a meaningful difference for the pre-test. As for control group, CCTDI total score average is in a rise at the final test, however this increase does not create a meaningful difference. When the results related with the six 
sub inventories of CCTDI are evaluated independently, it is seen that there is no meaningful difference for sub inventories. When the score average related with the inventory of both groups are analyzed, an increase is observed and understood that experiment group's increase in a higher rate. However, this increase is not as big as to make a difference statistically. As six subinventories of CCTDI are evaluated in terms of total score of the groups, though there is no meaningful difference between the sub inventories of analytic, broad minded, curiosity and self-confidence, it is determined that there is a meaningful difference between sub inventories of search for truth and systematic in favor of experiment group.

\section{Conclusion}

Under the conditions that there is no alternative except traditional teaching methods for education depending on the results got from the research, a more effective teaching can be done, at least, with the union of few different methods. It is observed that critical thinking tendency can't be improved meaningfully for student's subinventories analytic, curiosity and self-confidence with the improved method. Hence, studies should be done to get the student's this aspect improved in different mixed learning teaching models.

\section{Giriş}

Bireyin davranışlarında kendi yaşantısı yoluyla istendik davranış değiştirme süreci (Ertürk, 1972, s.12) olarak tanımlanan eğitim ve bireyin kendi yaşantısı yoluyla davranışlarında meydana gelen kalıcı izli davranış değişikliği (Varış 1988, s.11) olarak tanımlanan öğrenme kavramlarında 
ana tema davranış değişikliğinin bireyin kendi yaşantısında ve kalıcı izli olarak meydana gelmesidir. Bu tanımlardan yola çıkıldığı zaman eğitim ve öğrenme olaylarının bireylerin etkinliklerine dayandığı görülmektedir. Şimdilerde ise tamamen bireyin etkinliklerine dayanan, bireyi merkeze alıp onun ihtiyaç ve beklentilerine göre eğitim programlarının düzenlenmesi gerektiğini savunan ve bütün sistemin bireylere (öğrencilere) yönelik olarak hazırlanması gerektiğini vurgulayan yaklaşım “Öğrenci Merkezli Eğitim (ÖME)" olarak karşımıza çıkmaktadır (Titiz, 1999, s.12).

\section{Öğrenci Merkezli Ĕgitim}

ÖME, geleneksel eğitim olarak bilinen ve öğretmen kontrolünde gelişen derslerin yerine, öğrencinin sorumluluğunun ve etkinliklerinin ön plana alınması gerektiğini ve ayrıca geçmiş öğrenmelerini güçlü bir şekilde vurgulayan bir yaklaşımdır (Ingleton, Kiley, Cannon and Rogers, 2005, s.3). ÖME terimi öğretim ve öğrenme alan yazınında çok geniş anlamlarda kullanılmaktadır. Bu yüzden birçok terim öğrenci merkezli eğitim ile bağlantılıdır. Örneğin; esnek öğrenme, yaparak-yaşayarak öğrenme, kendi kendine öğrenme gibi. Bununla birlikte ÖME kavramından herkesin farklı bir anlam çıkardığı görülmektedir (O’Neill ve McMohan, 2005). Gerçekte öğrenci merkezli eğitim, bunların tümünü ve daha da fazlasını kapsamaktadır. Öğrenciye, dersin hedefleri doğrultusunda öğrenmesini sağlayacak, fakat öğrencinin sadece not almasını değil, etkin katılımına imkân verecek etkinlikleri içermektedir (Erbil, 2003). ÖME'de dersin planlanması diğer öğretmen ve öğrencilerle etkileşim, öğrenme ve düşünme yollarının belirlemesi gibi sorumluluklara öğrenci de katkıda bulunur (Ingleton, Kiley, Cannon ve Rogers, 2005, s.3; 
Prawat, 1992, s.359-378).

\section{Karma Öğretim Yöntemi}

Türkçe alan yazında ismi "karma öğrenme”, "harmanlanmış öğrenme", "k-öğrenme” ve "b-öğrenme" (KAYNAK, 2004; Ünal, 2007; Kaynar, 2007; Ünsal, 2006) modeli olarak, yabancı alan yazında ise, "blended learning", "mix learning", "b-learning" ve "Hybrid Learning" (ODP, 2003; Clark, 2006; Kapp ve McKeague, 2002; Oliver ve Trigwell, 2005; Aycock, Garnham, ve Kaleta, 2002) olarak kullanılan “karma öğretim yöntemi”, her türlü teknolojinin kullanılabildiği, geleneksel ve uzaktan eğitimin farklı model ve araçlarının bir araya getirilerek düzenlendiği, harmanlandığı öğretim yöntemidir (TBV, 2003). Başka bir tanıma göre ise karma öğretim; programın verimini ve amaçlanan öğrenme hedeflerinin en kolay şekilde gerçekleşmesini sağlamak için en uygun programa karar vermektir (Singh ve Reed, 2001, s.51-54).

İlk ortaya çıktığında e-öğrenme ve uzaktan eğitim gibi internet ve web tabanlı eğitim uygulamalarının özellikle insanları sosyallikten uzak ve tek başına yaşamaya itmesinden dolayı, bu eğitim uygulamalarının biraz daha etkileşimli hale getirilmesi amacıyla, birleştirilerek uygulanması ve daha etkili bir şekilde öğretim yapılması amaçlanmıştır. Sonraları bunlara yüzyüze yapılması gereken birtakım uygulamalar ve yöntemler de eklenmiştir. Bütün hepsinde amaç; hem mevcut sınıf içi ders uygulamalarına bir alternatif oluşturmak, hem de uzaktan eğitim ve e-öğrenmenin daha çok insanlarla etkileşimde bulunmayı gerektirecek bir uygulama biçimini bulmak olmuştur. Dolayısıyla karma 
öğretim temelde olabildiğince çok ve çeşitli eğitim aracı kullanmak anlamına gelmemektedir. Ancak şimdilerde uygulama şekliyle amaca en uygun ve daha iyi yöntemlerin birleştirilerek daha etkili hale getirilmesi şeklinde uygulanmaktadır (KAYNAK, 2006). Oliver ve Trigwell (2005) ise; kullanılan öğrenme teknolojilerine bakılmaksızın, birtakım pedagojik metotların bir birleşimi şeklinde açıklamaktadır.

Karma öğretim yönteminde başlıca iki tür uygulama ön plana çıkmaktadır. Bunlardan birincisi internet üzerinden yapılan eğitime, gerektiği ve ihtiyaç duyulduğu zamanlarda yüz yüze eğitimle destek olmaktır ki, bu uygulama türü sınıf dışı bir eğitim uygulaması olarak yürütülmektedir. Daha çok uzaktan eğitim kapsamında değerlendirilebilir. İkinci türü ise, sınıf içi eğitimde kullanılmasıdır. Bu uygulamada ise, sınıfta bulunan öğrencilerin kişisel özellikleri ile başta öğrenme stilleri ve dersin değişik boyutlardaki hedefleri dikkate alınarak, bütün hedefleri, bütün öğrencilere, aynı zamanda ve aynı şekilde öğretmek yerine; sınıftaki farklı öğrencilerin özelliklerine ve dersin farklı hedeflerinin özelliklerine uygun ve etkili yöntemlerle birlikte materyal ve kaynaklar belirlenerek, dersin sınıf içinde ve dışında ödevler ve projeler yardımıyla işlenmesidir. Bu türlü uygulanması öğrenci merkezli eğitim yaklaşımının ilke ve kurallarına da uygun düşmektedir. Bu çalışmada da öğrenci merkezli öğretim yöntem ve tekniklerinden uygun olanlarının uygun şekilde birleştirilmesi ve ders planı ve fiziki ortamın öğrencilere göre hazırlanarak geliştirilmiş olan yöntem, araştırmada “öğrenci merkezli karma öğretim yöntemi” olarak isimlendirilmiş ve uygulanmıştır. 


\section{Eleştirel Düşünme}

Düşünme insanlara varlığı ve çevresini, yereli ve küreseli, çok boyutluluğu, kısacası karmaşık olanı bir bütün olarak algılamayı sağlayan bir yetenektir (Morin, 2003, s.71). Eleştirel düşünme ise; öneri ve kanıtların dikkatli değerlendirilmesine dayanan ve ilgili tüm etmenleri hesaba katarak nesnel bir yolla sonuçlara varan, mantığın geçerli yöntemlerini kullanan bir düşünme türü (Öncül, 2000, s.424) veya karar vermeyi etkileme, mantıklı bir şekilde şüpheciliği sürdürme ve açık fikirlilik (Dewey, 2007) olarak tanımlanmaktadır.

Eleştirel düşünme, kişinin düşünce sistemindeki yapıları usta bir şekilde yöneterek ve bu yapılara entelektüel standartlar getirerek düşünme yönteminin kalitesini artırdığı bir süreçtir (Paul ve Elder, 2007, s.9-10). Öğrencilerin öğrendikleri bilgileri problemlerin çözümünü en kısa zamanda ve en iyi şekilde yapabilmek için yorumlama, analiz etme ve değerlendirmenin yanında problemin sonuçlarını kendi yararına ve en iyi şekilde kullanmadır (Atlas, 2006). Eleştirel düşünmenin, aktif bir zihinsel işlem gerektirdiği ve kalıpların dışına çıkma, görünenin ve bilinenin dışında, asıl nedeni bulma gibi anlamları da bulunmaktadır.

Eleştirel düşünebilme eksikliği çeken öğrencilerin sıradan, sözel problemlerde bile çözüme gidebilecek uygun muhakemeyi uygulayamadıkları görülmektedir (McKendree, Small ve Stenning, 2002, s.2). 2000'li yıllarla beraber, yaşam biçiminin internet ve diğer teknolojik gelişmelere bağlı olması sonucunda bilgi teknolojileri önem kazanmıştır. Modern toplumdaki hızlı ve karmaşık değiş̧ikliklere cevap ve- 
rebilme açısından eleştirel düşünme daha da önemli bir rol üstlenmeye başlamıştır (McKendree, Small ve Stenning, 2002, s.2).

Bütün bu özellikleri düşünüldüğü zaman eleştirel düşünme becerisinin kazandırılması için özel birtakım uygulamaların gerekli olduğu anlaşılmaktadır. Bu uygulamalar ise, önceki bölümde incelenen öğrenci merkezli eğitim anlayışının felsefesine uygun olursa, eleştirel düşünme becerisini geliştirmede başarılı sonuçlar alınabilir. Çünkü normal, sıradan, klasik ve tek düze birtakım yöntem ve teknikler, daha doğrusu öğrenciyi pasif kılacak ve sürece katılmasını önleyecek yöntem ve tekniklerin, eleştirel düşünme becerisini geliştirme konusunda çok fazla şansı görülmemektedir. Çünkü eleştirel düşünme aktif, üretken, yaratıcı ve dinamik bir zihin yapısını gerekli kılmaktadır. Bu tür zihinsel işlemleri öğrencilere öğretebilmek için ise, geleneksel ve öğretmen merkezli yöntemlerin kullanılması düşünülemez. Bu yüzden öğrenci merkezli eğitimin ve öğrenci merkezli eğitim temelinde hazırlanan müfredat ve ders programlarının, öğrencilerde eleştirel düşünme becerisini artıracağı tahmin edilmektedir.

Öğrencilerin eleştirel düşünme becerilerinin gelişmesinde öğretmen çok önemli bir işleve sahiptir. Öğretmen öğrencilerinin bu becerilerinin gelişimi için gerek dersini planlarken, gerekse uygularken çeşitli etkinliklere yer verebilir ya da önlemler alabilir (Özdemir, 2005, s.6). Öğretmenin eleştirel düşünmenin gelişmesi için sınıftaki temel görevi, sınıf ortamını ve koşullarını en uygun hale getirmektir. Özellikle sınıf atmosferini öğrencilerin kendilerini rahatça ifade edebilecekleri bir hale getirmek öğretmenin görevidir (Aybek, 2007). Sınıf ortamının öğrencilerin rahat hareket edebilecekleri bir şekilde hazır- 
lanması ve diğer öğretim şartlarının (öğretim materyalleri, kaynaklar, kullanılan yöntem, zaman vb.) eleştirel düşünme becerisini geliştirmeye yönelik olarak hazırlanması için, öğrenci merkezli eğitimin ilke ve kurallarından yararlanılabilir. Çünkü öğrencilerin aktif olarak derse katılmaları, düşünme süreçlerini aktif olarak kullanmaları, kendi öğrenme sorumluluklarını alarak, öğrenme olayını gerçek anlamda gerçekleştirebilmeleri gibi ilkeler öğrenci merkezli eğitimin ilke ve öğretileriyle uyuşmaktadır. O halde eleştirel düşünme becerisinin öğretilmesi veya geliştirilmesinde öğrenci merkezli eğitim uygulamalarından yararlanılabilir.

\section{Araştırmanın Amacı}

$\mathrm{Bu}$ araştırmanın genel amacı, öğrenci merkezli eğitime dayalı olarak geliştirilmiş olan karma öğretim yönteminin Öğretimde Planlama ve Değerlendirme dersinde öğrencilerin eleştirel düşünme eğilimlerine etkisini saptamaktır.

\section{Denenceler}

$\mathrm{Bu}$ amaç doğrultusunda aşağıdaki denenceler test edilmiştir.

1. Deney ve kontrol grubunun ön test eleştirel düşünme becerisi puan ortalamaları arasında anlamlı bir fark yoktur.

2. Deney grubunun ön test ve son test eleştirel düşünme becerisi puan ortalamaları arasında son test lehine anlamlı fark vardır. 
3. Kontrol grubunun ön test ve son test eleştirel düşünme becerisi puan ortalamaları arasında son test lehine anlamlı fark vardır.

4. Deney ve kontrol gruplarının son test eleştirel düşünme becerisi puan ortalamaları arasında deney grubunun lehine anlamlı fark vardır.

\section{Yöntem}

\section{Araştırmanın Modeli}

Araştırma, deneysel yöntemlerden birisi olan ön test-son test kontrol gruplu modele göre desenlenmiştir. Bağımsız değişken Öğrenci Merkezli Karma Öğretim Yöntemi, bağımlı değişken ise Eğitim Fakültesi Sosyal Bilgiler Öğretmenliği 2. sınıf öğrencilerinin eleştirel düşünme becerileri olmuştur.

\section{Çalışma Grubunun Seçilmesi}

Deneyin yapılacağı deney ve kontrol gruplarının oluşturulması için, öğrencilerle ilgili (a) öğrencilerin Öğrenci Seçme Sınavı (ÖSS) puanları, (b) birinci sınıftaki (2005-2006) güz dönemi akademik başarı ortalamaları, (c) ve bahar dönemi akademik başarı ortalamaları, (d) ikinci sınıftaki (2006-2007) güz dönemi akademik başarı ortalamaları, (e) birinci sınıftaki (2005-2006) güz dönemi “Öğretmenlik Mesleğine Giriş" dersi akademik başarı ortalamaları, (f) birinci sınıftaki (2005-2006) bahar dönemi “Gelişim ve Öğrenme Psikolojisi” dersi akademik başarı ortalamaları gibi ölçütler kullanılarak Türkçe öğret- 
menliğinden 98, sosyal bilgiler öğretmenliğinden ise 93 öğrencinin verileri hiyerarşik olmayan kümeleme analizine tâbi tutulmuştur.

\section{Ders Planının Uygulanması}

Dörtlü atama yapılarak 83 kişi ile en çok öğrencinin bulunduğu ikinci grup olan sosyal bilgiler öğretmenliği birinci ve ikinci öğretimi öğrencileri araştırmaya alınmıştır. Bu öğrencilerden de 35'er öğrenci seçilerek araştırma onlar üzerinde yürütülmüştür. İkinci grupta yer alan 83 öğrenciden 39 tanesi bir sınıfta, geriye kalan 44 tanesi ise diğer sınıfta çıkmışlardır. Her iki sınıftan da sivri uçlardaki öğrenciler çıkarılarak çalışma grupları 35 ’te eşitlenmiştir.

Bir haftası hazırlık olmak üzere toplam altı hafta süren deneysel uygulama ders planları doğrultusunda yapılmıştır. Deneysel uygulamanın yapıldığı altı hafta boyunca yapılan çalışmalar şu şekildedir:

Deneysel uygulamanın ilk haftası uygulamada kullanılacak olan ders programının ayrıntılarını içeren bir grupla çalışma rehberinin bütün öğrencilere dağıtılması ve bu rehber üzerinde bütün sınıfın kat1lımıyla bir tartışma ortamında geçmiştir.

Dersin işlenmesi ilk olarak işbirlikli öğrenme ayrılıp birleşme tekniği ile başlamıştır. Daha sonra akvaryum tekniğinin uygulanması için hazırlıklar yapılmıştır. Bu yöntemin uygulanabilmesi için normalde bütün sınıfın iç içe iki daire şeklinde oturması gerekmektedir, ancak sınıfın fiziki ortamı buna izin vermediğinden dolayı en uygun oturma düzeni oluşturulmaya çalışılmıştır. Son olarak da beyin firtınası tekniğine geçilmiştir. Bu tekniğin uygulanmasında da zaman zaman değişiklikler yapılarak, öğrencilerin istekleri ve beklentileri dikkate 
alınmıştır. Son teknik olan beyin firtınası da uygulandıktan sonra öğrencilerin ellerinde bulunan değerlendirme formları aracilığıyla (bunu öğrenmek istiyorum, kayıt çizelgesi ve grup çalışması öğrenci değerlendirme formu) hem kendilerini hem de diğer arkadaşlarını değerlendirmeleri ve ders hakkındaki görüşlerini yazmaları istenmiştir. Aynı şekilde öğretici de öğrenciler hakkındaki değerlendirmesini önceden hazırlanan grup çalışması öğretmen değerlendirme formu aracıllığ ile yapmıştır.

Kontrol grubunda dersin işlenişi ise anlatım ve soru cevap yönteminin birlikte kullanılması şeklinde gerçekleşmiştir. Öğreticinin dersi anlatım yöntemiyle işlemesinin akabinde konuları pekiştirmek amacryla ders aralarında ve konu geçişlerinde soru cevap yönetimine başvurulmuştur.

\section{Araştırmada Kullanılan Yöntemlerin Seçilmesi}

Araştırmada en öncelikli amaç, öğrenci merkezli bir ders uygulamasının öğrenciler üzerindeki etkisi olduğu için, yöntemlerin seçiminde ilk olarak bu nokta dikkate alınmıştır. Bu bakımdan alan yazında öğrenci merkezli uygulamalara açık olması, öğrencileri sınıf ortamında düşünmeye ve çalışmaya yönlendirmesi, hem grupla hem de bireysel olarak çalışmaya sevk etmesi ve sorumluluk almayı gerekli kılması (Demirel, 2003, s.120-124) gibi araştırmanın amacına uygun olan birçok özelliğinden dolayı "İşbirlikli (Kubaşık) Öğrenme Modeli" araştırmada “Öğrenci Merkezli Karma Öğretim Yöntemi”nin en temel parçasını oluşturmuştur. 
Akvaryum yöntemi deneyim ve görüşlerin paylaşılması için geliştirilmiş bir metottur (Gottlieb, 2005). Yöntemle sınıf içi tartışmaları canlandırmak, mümkün olduğu kadar çok sayıda öğrenciyi tartışmaya katmak için de kullanılır (Açıkgöz, 2005, s.129). Akvaryum yönteminin deneysel uygulama için kullanılacak olan "Öğrenci Merkezli Karma Öğretim Yöntemi” içerisinde yer almasında, yöntemin bütün sınıfla birlikte yapılıyor olması, konuyu irdelemeye ve değişik fikirlerin ortaya çıkmasına yardımcı oluyor olması ve daha önceden çok fazla denenmemiş olması da etkili olmuştur.

Beyin fırtınası yöntemi, araştırmada dersin değerlendirmesi ve kontrol amaçlı kullanılmıştır. Bu yöntemin belirlenmesi aşamasında, diğer iki yöntemi tamamlayacak, aynı zamanda işlenen konuların da bir değerlendirmesinin yapılmasına olanak sağlayacak bir yöntem olması düşünülmüştür. Özellikle ders boyunca ve önceden yapılan hazırlık sırasında öğrenilenlerin hiçbir müdahale olmadan ve özgür bir şekilde ifade edilmesine imkân veren bir yöntem olmasından, öğrencileri üretkenliğe ve belli bir konuda değişik görüşler elde etmede etkili olduğundan (Yavuz, 2005, s.116) dolayı beyin firtınası yöntemi deney için kullanılan son yöntem olarak seçilmiştir.

\section{Verilerin Toplanması ve Analizi}

Veriler, Eleştirel Düşünme Eğilimi Ölçeği (The California Critical Thinking Disposition Inventory-CCTDI) ile toplanmıştır. Bu ölçek 1990 yılında Amerikan Felsefe Derneği'nin düzenlediği Delphi projesinin bir sonucu olarak ortaya çıkmıştır. Orjinali İngilizce olan ölçek yedi boyut ve 75 maddeden oluşmaktadır. Ölçeğin derecelendi- 
rilmesi "tamamen katılıyorum"dan "hiç katılmıyorum”a kadar uzanan altı bölümlü şekilde yapılmıştır. Farklı bir kültürde uygulanacak olmasından dolayı hem faktör yapısının, hem de tek tek maddelerin farklılaşması mümkün olduğundan ölçek Türkçe'ye çevrilmiş ve Başkent Üniversitesi, İktisadi ve İdari Bilimler Fakültesi'nde okuyan ve yaşları 17-28 arasında değişen 913 öğrenciyle (468 kız, 445 erkek) uygulama yapılmıştır. Uygulama sonucu iki faktör (Açık Fikirlilik ve Olgunluk) birleşmiş ve ölçek 6 boyut toplam 51 maddeden oluşmuştur (Kökdemir, 2003). Yeni şekillenen ölçeğin güvenirliğinin bir göstergesi olarak iç tutarlılık katsayısı (cronbach alfa) .88 olarak bulunmuştur. Kökdemir (2003) tarafından Türkçeye uyarlanan ve güvenirlik ve geçerlik çalışması yapılan ilgili anket araştırmanın veri toplama aracı olarak kullanılmıştır.

\section{Verilerin Analizi}

Verileri değerlendirmek için ölçekten elde edilen puan ortalamaları kullanılmıştır. Buna göre öncelikle dağılımın homojenliğini belirlemek amacıyla genel ve alt ölçekler açısından Levene testi yapılmış, homojen gruplarda bağımlı ve bağımsız gruplar $t$ testi yapılmış, homojen olmayan dağılımda ise bağımlı gruplarda Wilcoxon İşaretli Sıralar testi uygulanmıştır.

\section{Bulgular}

Araştırmanın bulguları, denencelere ve CCTDI alt ölçeklerine göre yorumlanmaya çalışılmıştır. 


\section{Birinci Denenceye İlişkin Bulgular ve Yorum}

Birinci denencede, deneysel uygulama öncesinde oluşturulan grupların eleştirel düşünme eğilimi açısından da birbirine eşit olup olmadıkları test edilmiştir.

Tablo 1. Grupların CCTDI Ön Test Genel ve Alt Ölçek Puan Ortalamaları ve Bağımsız Gruplar $t$ Testi Sonuçları

\begin{tabular}{lllllllc}
\hline Gruplar & & $\mathbf{N}$ & $\bar{X}$ & s.s. & $\mathbf{r}$ & $\mathbf{t}$ & $\mathbf{p}$ \\
\hline \multirow{2}{*}{ Genel } & Deney & 35 & 4.28 & 0.37 & 0.18 & 1.88 & 0.06 \\
& Kontrol & 35 & 4.20 & 0.42 & & & \\
\hline \multirow{2}{*}{ Analitik } & Deney & 35 & 4.96 & 0.57 & 0.88 & 1.00 & 0.31 \\
& Kontrol & 35 & 4.82 & 0.57 & & & \\
\hline Açık & Deney & 35 & 4.18 & 0.55 & 0.50 & -0.17 & 0.86 \\
Fikirlilik & Kontrol & 35 & 4.20 & 0.57 & & & \\
\hline Meraklılık & Deney & 35 & 4.60 & 0.73 & 0.65 & 0.51 & 0.61 \\
& Kontrol & 35 & 4.51 & 0.80 & & & \\
\hline Kendine & Deney & 35 & 4.17 & 0.56 & 0.16 & 0.68 & 0.49 \\
Güven & Kontrol & 35 & 4.02 & 1.09 & & & \\
\hline Doğruyu & Deney & 35 & 3.26 & 0.86 & 0.45 & 0.49 & 0.62 \\
Arama & Kontrol & 35 & 3.16 & 0.72 & & & \\
\hline Sistematiklik & Deney & 35 & 4.19 & 0.68 & \multirow{2}{*}{0.21} & 0.44 & 0.65 \\
& Kontrol & 35 & 4.11 & 0.82 & & & \\
\hline D. & & & & & & &
\end{tabular}

$\mathrm{p}>.005 \quad \mathrm{sd}=68$

Tabloda görüldüğü gibi deney grubunun genel ortalaması $(\bar{X}=4,28)$ kontrol grubunun ortalamasından $(\bar{X}=4,20)$ biraz yüksek olmakla birlikte, $t$ testi sonuçlarına göre $(\mathrm{t}=1,87)$ anlamlı bir farklılık mevcut değildir ( $\mathrm{p}>.05)$. Buna göre uygulama öncesi deney ve kontrol grubunun eleştirel düşünme eğilimi eşittir denilebilir.

\section{İkinci Denenceye İlişkin Bulgular ve Yorum}

Deney grubunun eleştirel düşünme eğilimindeki gelişiminin de- 
neysel uygulamaya bağlı olup olmadığını belirlemek amacıyla grubun CCTDI ön test ve son test puanları üzerinde yapılan Levene testine göre genel, analitiklik, açık fikirlilik ve meraklılık alt ölçeklerinde dağılım homojen çıkmadığı için Wilcoxon İşaretli Sıralar testi yapılmış ve sonuçları Tablo 2'de verilmiştir.

Tablo 2: Deney Grubu CCTDI Ön Test-Son Test Toplam Puanları Wilcoxon İşaretli Sıralar Testi Sonuçları

\begin{tabular}{|c|c|c|c|c|c|c|c|c|c|}
\hline & $\mathbf{N}$ & $\bar{X}$ & S.S. & & $\mathbf{N}$ & Sira ort. & Sira & $\mathbf{Z}$ & $\mathbf{p}$ \\
\hline \multirow{2}{*}{$\begin{array}{l}\text { Genel } \\
\text { Ön Test }\end{array}$} & \multirow[t]{2}{*}{35} & \multirow[t]{2}{*}{4,28} & \multirow[t]{2}{*}{, 38} & $\begin{array}{l}\text { Negatif } \\
\text { Sira }\end{array}$ & 7 & 10.14 & 71,0 & \multirow{3}{*}{$-3,9 *$} & \multirow{3}{*}{0.00} \\
\hline & & & & $\begin{array}{l}\text { Pozitif } \\
\text { Sura }\end{array}$ & 27 & 19,41 & 524,0 & & \\
\hline Son Test & 35 & 4,46 &, 43 & Eşit & 1 & & & & \\
\hline \multirow{3}{*}{$\begin{array}{l}\text { Analitiklik } \\
\qquad \begin{array}{l}\text { Ön Test } \\
\text { Son Test }\end{array}\end{array}$} & \multirow[t]{2}{*}{35} & \multirow[t]{2}{*}{4,96} & \multirow[t]{2}{*}{, 57} & $\begin{array}{c}\text { Negatif } \\
\text { Sira }\end{array}$ & 11 & 13.14 & 144.50 & & \\
\hline & & & & Pozitif & 19 & 16.87 & 320.50 & 1.81 & 0.07 \\
\hline & 35 & 5.13 &, 50 & & 5 & & & & \\
\hline \multirow{2}{*}{$\begin{array}{r}\text { Açı fikirlilik } \\
\text { Ön Test }\end{array}$} & \multirow{2}{*}{35} & \multirow{2}{*}{4,18} & \multirow{2}{*}{, 58} & $\begin{array}{l}\text { Negatif } \\
\text { Sira }\end{array}$ & 9 & 16.22 & 146.0 & \multirow{3}{*}{$2.77 *$} & \multirow{3}{*}{0.00} \\
\hline & & & & $\begin{array}{l}\text { Pozitif } \\
\text { Sura }\end{array}$ & 26 & 18.62 & 484.0 & & \\
\hline Son Test & 35 & 4,51 &, 55 & Eşit & - & - & - & & \\
\hline \multirow{3}{*}{$\begin{array}{l}\text { Meraklılık } \\
\text { Ön Test }\end{array}$} & \multirow[t]{2}{*}{35} & \multirow[t]{2}{*}{4,60} & \multirow[t]{2}{*}{, 73} & $\begin{array}{l}\text { Negatif } \\
\text { Sira }\end{array}$ & 17 & 15.26 & 259.50 & \multirow{3}{*}{-0.08} & \multirow{3}{*}{0.93} \\
\hline & & & & $\begin{array}{l}\text { Pozitif } \\
\text { Sira }\end{array}$ & 15 & 17.90 & 268.50 & & \\
\hline & 35 & 4,63 &, 77 & Eşit & 3 & & & & \\
\hline
\end{tabular}

Deney grubunun CCTDI genel ön test $(X=4,28)$ ve son test $(X=4,46)$ puan ortalamaları $(Z=-2,83)$, arasında anlamlı bir farklılık olduğu anlaşılmaktadır $(\mathrm{p}<.05)$. Sıra ortalamalarına bakıldığında, son test sıra ortalamalarının (pozitif sıralar) daha yüksek olduğu görülmektedir. Bu sonuçlara göre deneysel uygulamanın deney grubunun 
eleştirel düşünme eğilimini geliştirmede etkili olduğu söylenebilir. Alt ölçekler açısından bakıldığında ise CCTDI analitiklik alt ölçeği (ön test $X=4,96$ ve son test $X=5,13$ ) CCTDI merakl1lık alt ölçeği (ön test $X=4,60$ ve son test $X=4,63$ ) son test sira ortalamaları daha yüksek olmakla birlikte CCTDI analitiklik ( $\mathrm{Z}=-1,81 ; \mathrm{p}>$.05) CCTDI meraklılık $(\mathrm{z}=-, 93 ; \mathrm{p}>.05)$ alt ölçeklerinde istatistiksel açıdan anlamlı bir farkın oluşmadığı belirlenmiştir. CCTDI Açık fikirlilik alt ölçeği ön test $(X=4,18)$ ve son test $(X=4,51)$ ortalamaları arasında anlamlı bir fark bulunmaktadır $(\mathrm{Z}=-2,77 ; \mathrm{p}<.05) . \mathrm{Bu}$ farklılığın sira ortalamalarına bakıldığında son test lehine olduğu görülmektedir.

Tablo 3: Deney Grubu CCTDI Ön Test ve Son Test Genel ve Alt Ölçek Puan Ortalamaları ve Bağımlı Gruplar $t$ Testi Sonuçları

\begin{tabular}{|c|c|c|c|c|c|c|c|}
\hline Gruplar & & $\mathbf{N}$ & $\bar{X}$ & S.S. & $\mathbf{R}$ & $\mathbf{t}$ & p \\
\hline Kendine & Ön test & 35 & 4.17 & 0.56 & \multirow{2}{*}{0.25} & \multirow{2}{*}{$-1.98 *$} & \multirow{2}{*}{0.05} \\
\hline Güven & Son test & 35 & 3.91 & 0.66 & & & \\
\hline Doğruyu & Ön test & 35 & 3.26 & 0.86 & \multirow{2}{*}{0.14} & \multirow{2}{*}{$2.47 *$} & \multirow{2}{*}{0.01} \\
\hline Arama & Son test & 35 & 3.71 & 0.78 & & & \\
\hline \multirow{2}{*}{ Sistematiklik } & Ön test & 35 & 4.19 & 0.68 & \multirow{2}{*}{0.53} & \multirow{2}{*}{$1.97 *$} & \multirow{2}{*}{0.05} \\
\hline & Son test & 35 & 4.50 & 0.72 & & & \\
\hline
\end{tabular}

$\mathrm{p}>.005 \quad \mathrm{sd}=34$

Tablo 3'te deney grubunun CCTDI Kendine Güven alt ölçeği ön test $(X=4,17)$ ve son test $(X=3,91)$ ortalamaları deneysel uygulama öncesi ve sonrası aldıkları puan ortalamaları arasında $t$ testi sonuçlarına göre $(\mathrm{t}=-1,98)$ anlamlı bir farklılık belirlendiği görülmektedir $(\mathrm{p}<.05)$. Farklılığın nereden kaynaklandığını anlamak için ortalamalara bakıldığı zaman, son test ortalamasının, ön test ortalamasından daha düşük 
olduğu görülmektedir. Bu değer deneysel uygulama sonrasında öğrencilerin kendine güven eğilimlerinde bir değişiklik olduğunu ancak bu değişikliğin olumsuz yönde olduğunu göstermektedir. O halde deneysel uygulama deney gurubunda bulunan öğrencilerin eleştirel düşünme eğilimini kendine güven alt boyutunda anlamlı ve negatif derecede etkilemiştir denilebilir. CCTDI doğruyu arama alt ölçeği (ön test $X=3,26$ ve son test $X=3,71, \mathrm{t}=2,47)$ ve CCTDI sistematiklik alt ölçeği (ön test $X=4,19$ ve son test $X=4,50, \mathrm{t}=1,97$ ) açısından bakıldığında ise deneysel uygulama öncesi ve sonrası puan ortalamaları arasında, anlamlı bir farklılık bulunmaktadır $(\mathrm{p}<.05)$. Ön test ve son test puan ortalamaları dikkate alındığında, son test ortalamasının ön test ortalamasından daha yüksek olduğu, bu yüzden de anlamlı farklılığın son test lehine olduğu anlaşılmaktadır. Bu bulgulara dayanarak deney grubunda bulunan öğrencilerin eleştirel düşünme eğilimlerinin deneysel uygulama sonrasında anlamlı derecede geliştiği ancak alt ölçekler açısından yeterli olmadığı söylenebilir.

\section{Üçüncü Denenceye İlişkin Bulgular ve Yorum}

Kontrol grubunun ön test son test ortalamaları ve $t$ testi sonuçları Tablo 4'te verilmiştir. 
Tablo 4. Kontrol Grubu CCTDI Ön Test ve Son Test Genel ve Alt Ölçek Puan Ortalamaları ve Bağımlı Gruplar $t$ Testi Sonuçları

\begin{tabular}{lccccccc}
\hline Gruplar & & $\mathbf{N}$ & $\bar{X}$ & s.s. & $\mathbf{R}$ & $\mathbf{t}$ & $\mathbf{p}$ \\
\hline \multirow{2}{*}{ Genel } & Ön test & 35 & 4.20 & 0.42 & & & \\
& Son test & 35 & 4.28 & 0.35 & 0.29 & 1.07 & 0.29 \\
\multirow{2}{*}{ Analitiklik } & Ön test & 35 & 4.82 & 0.57 & & & \\
& Son test & 35 & 5,01 & 0.45 & 0.32 & 1.85 & 0.07 \\
Açık fikirlilik & Deney & 35 & 4.20 & 0.57 & & & \\
& Kontrol & 35 & 4.40 & 0.56 & & 1.59 & 0.12 \\
Meraklılık & Ön test & 35 & 4.51 & 0.80 & 0.26 & 0.47 & 0.63 \\
& Son test & 35 & 4.58 & 0.69 & & & \\
\hline Kendine & Ön test & 35 & 4.02 & 1.09 & \multirow{2}{*}{0.91} & -1.37 & 0.17 \\
güven & Son test & 35 & 3.73 & 0.62 & & & \\
\hline \multicolumn{1}{c}{ p>0.005 } & sd=34 & & & & & &
\end{tabular}

CCTDI'nın genel ön test $(X=4,20)$ ve son test $(X=4,28)$ puan ortalamaları son testte artmıştır. Ancak, bu bu artış ( $\mathrm{t}=1,07)$, anlamlı farklılık oluşturmamıştır ( $\mathrm{p}>.05$ ). Buna dayanarak, kontrol grubunda işlenen dersin öğrencilerin eleştirel düşünme eğiliminde anlamlı farklılık oluşturacak kadar bir gelişime sebep olmadığı söylenebilir. CCTDI analitiklik (ön test $X=4,82$ ve son test $X=5,01, \mathrm{t}=1,85$ ) CCTDI açık fikirlilik (ön test $X=4,20$ ve son test $X=4,40, \mathrm{t}=1,59$ ), CCTDI merakl1l1k (ön test $X=4,51$ ve son test $X=4,58 \mathrm{t}=47$ ), CCTDI kendine güven (ön test $X=4,02$ ve son test $X=3,73, \mathrm{t}=-1,37$ ) alt ölçekleri puan ortalamaları arasında $t$ testi sonuçlarına göre anlamlı bir farklılık bulunmamaktadır ( $p>.05)$. Analiz sonuçlarına dikkat edildiği zaman gurubun kendine güven alt ölçeğinde ön test puan ortalamalarının ile son test puan or- 
talamalarına göre daha yüksek olduğu görülmektedir.

Tablo 5: Kontrol Grubu CCTDI Ön Test ve Son Test Genel ve Alt Ölçek Puan Ortalamaları Wilcoxon İşaretli Sıralar Testi Sonuçları

\begin{tabular}{|c|c|c|c|c|c|c|c|c|c|}
\hline & $\mathbf{N}$ & $\bar{X}$ & S.S. & & $\mathbf{N}$ & Sira ort & Sira top & $\mathbf{Z}$ & $\mathbf{p}$ \\
\hline $\begin{array}{c}\text { Doğruyu } \\
\text { Arama }\end{array}$ & 35 & 3.16 & 83 & $\begin{array}{l}\text { Negatif } \\
\text { Sira }\end{array}$ & 12 & 17.75 & 213,0 & & \\
\hline Ön Test & & & & $\begin{array}{l}\text { Pozitif } \\
\text { Sira }\end{array}$ & 19 & 14.89 & 283,0 & -0.68 & 0.49 \\
\hline Son Test & 35 & 3.31 &, 72 & Eşit & 4 & & & & \\
\hline $\begin{array}{c}\text { Sistematiklik } \\
\text { Ön Test }\end{array}$ & 35 & 4,11 &, 82 & $\begin{array}{l}\text { Negatif } \\
\text { Sira }\end{array}$ & 14 & 15.68 & 219.50 & -0.2 & \\
\hline Son Test & 35 & 4.15 & ,62 & $\begin{array}{l}\text { Pozitif } \\
\text { Sıra } \\
\text { Eşit }\end{array}$ & 16 & 15.34 & 245.50 & 6 & 78 \\
\hline
\end{tabular}

Üçüncü denenceye ilişkin genel bulgular ve alt ölçekler boyutundaki bulgular değerlendirildiğinde; kontrol grubunda bulunan öğrencilerin ön test ve son test eleştirel düşünme eğilimleri arasında anlamlı bir farklılık oluşmadığı söylenebilir. Ancak, kendine güven alt ölçeğinde kontrol grubunda bulunan öğrencilerin son testte puan ortalamalarının daha düşük çıkması dikkat çekicidir. Kontrol grubunun ön test ve son test puan ortalamaları üzerinde yapılan analizler sonucunda gerek genel gerekse kendine güven alt ölçeği haricinde alt ölçekler açısından geleneksel öğretim yöntemlerinin de eleştirel düşünme eğilimlerini artırdığı ancak anlamlı farklılık oluşturmadığı söylenebilir.

\section{Dördüncü Denenceye İlişkin Bulgular}

$\mathrm{Bu}$ denenceyi belirlemeye yönelik iki grubun deneysel uygulama 
sonrası ilgili ölçeğin genelinden aldıkları puanlar üzerinde yapılan bağımsız gruplar $t$ testinin sonuçları Tablo 5 'te verilmiştir.

Tablo 6: Grupların CCTDI Son Test Genel ve Alt Ölçek Puan Ortalamaları ve Bağımsız Gruplar $t$ Testi Sonuçları

\begin{tabular}{llcccccc}
\hline Gruplar & & $\mathbf{N}$ & $\bar{X}$ & S.s. & $\mathbf{R}$ & $\mathbf{T}$ & $\mathbf{p}$ \\
\hline \multirow{2}{*}{ Genel } & Deney & 35 & 4.46 & 0.43 & 0.18 & \multirow{2}{*}{1.88} & 0.06 \\
& Kontrol & 35 & 4.28 & 0.35 & & & \\
\hline \multirow{2}{*}{ Analitiklik } & Deney & 35 & 5.13 & 0.50 & \multirow{2}{*}{0.69} & \multirow{2}{*}{1.07} & 0.28 \\
& Kontrol & 35 & 5.01 & 0.45 & & & \\
\hline Açık fikirli- & Deney & 35 & 4.51 & 0.58 & \multirow{2}{*}{0.99} & 0.79 & \multirow{2}{*}{0.42} \\
lik & Kontrol & 35 & 4.40 & 0.56 & & & \\
\hline Meraklılık & Deney & 35 & 4.63 & 0.77 & \multirow{2}{*}{0.28} & 0.26 & 0.79 \\
& Kontrol & 35 & 4.58 & 0.69 & & & \\
\hline Kendine & Deney & 35 & 3.91 & 0.66 & \multirow{2}{*}{0.88} & \multirow{2}{*}{1.19} & 0.23 \\
güven & Kontrol & 35 & 3.73 & 0.62 & & & \\
\hline Doğruyu & Deney & 35 & 3.71 & 0.78 & \multirow{2}{*}{0.79} & $2.04 *$ & 0.04 \\
arama & Kontrol & 35 & 3.31 & 0.83 & & & \\
\hline Sistematiklik & Deney & 35 & 4.50 & 0.72 & \multirow{2}{*}{0.57} & \multirow{2}{*}{$2.18^{*}$} & \multirow{2}{*}{0.03} \\
& Kontrol & 35 & 4.15 & 0.62 & & & \\
\hline \multicolumn{1}{c}{ p>.005 } & sd=68 & & & & & &
\end{tabular}

Tablo 5'te görüldüğü gibi CCTDI deney grubunun genel ortalamas1 ( $X=4,46)$ kontrol grubunun genel ortalamasından $(X=4,28)$ yüksek olmakla birlikte, $t$ testi sonuçlarına göre $(\mathrm{t}=1,88)$, anlamlı bir farklılık mevcut değildir ( $\mathrm{p}>.05)$. Aritmetik ortalamalar dikkate alındığında iki grubun testten aldıkları puanların ortalamaları arasında deney grubunun lehine sayısal bir fark dikkat çekmektedir, ancak bu fark anlamlı derecede değildir. Bir başka deyişle deneysel uygulama deney grubunda bulunan öğrencilerin eleştirel düşünme eğilimlerini, kontrol 
grubunda bulunan öğrencilerin eleştirel düşünme eğiliminden anlamlı farklılık oluşturmayacak derecede, daha yüksek oranda değiştirmiştir. Dördüncü denencenin bulgularına alt ölçekler açısından bakıldığında ise CCTDI analitiklik (deney $X=5,13$, kontrol $X=5,01, \mathrm{t}=1,07$ ) CCTDI açık fikirlilik (deney $X=4,51$ ve kontrol $X=4,40, \mathrm{t}=0,79$ ) CCTDI merakl111k, (deney $X=4,63$, kontrol $X=4,58, \mathrm{t}=0,26$ ), CCTDI kendine güven alt ölçeğine (deney $X=3,91$ ve kontrol $X=3,73, \mathrm{t}=1,19$ ) deney grubu puan ortalamalarının kontrol grubuna göre yüksek olmakla birlikte $t$ testi sonuçlarına göre anlamlı farklılık bulunmamaktadır ( $\mathrm{p}>.05)$. Ayrıca, kendine güven alt ölçeğine ilişkin veriler incelendiğinde deney grubunun ortalamaları daha yüksek olsa da, iki grubun da ön test verilerine bakıldığı zaman, kendine güven alt boyutunda eleştirel düşünme eğiliminin azaldığı görülmektedir.

Dördüncü denenceye ait bulgular genel olarak değerlendirildiğinde öğrenci merkezli karma öğretim yönteminin, geleneksel yönteme göre öğrencilerin eleştirel düşünme becerilerini daha çok geliştirdiği, ancak geleneksel yöntemin de, eleştirel düşünme becerilerini geliştirme konusunda etkili olduğundan dolayı, iki grup arasında genel puanlarda anlamlı bir farklılık oluşmadığı söylenebilir.

$\mathrm{Bu}$ veriler deneysel uygulama sonrasinda deney grubunda bulunan öğrencilerin eleştirel düşünme eğilimlerinin deneysel uygulamaya bağlı olarak bir miktar arttığını, fakat bu artışın anlamlı bir farklılık oluşturmadığını göstermektedir. İlgili grupların verilerinin analizinden elde edilen bulgular, ön test verilerinin analizinden elde edilen bulgularla karşılaştırıldığı zaman, her iki grupta da ortalamalar arasında 
doğru orantılı bir artış gözlenmektedir. Alt ölçekler açısından bakıldığında ise kontrol grubunda da eleştirel düşünme eğilimi gelişmiş ancak doğruyu arama ve sistematiklik alt ölçeği haricinde bu gelişim anlamlı farklılık oluşturmamıştır. Bunun yanında doğruyu arama alt ölçeğinde her iki grupta da eğilim ön test ve son test açısından diğer alt ölçeklere göre düşük olmasına rağmen deneysel çalışma bu eğilimin gelişimini geleneksel yöntemlere oranla anlamlı farklılık oluşturacak şekilde geliştirmiştir.

\section{Sonuç / Tartışma}

Öğretim ile ilgili alternatif uygulamaların etkililiği üzerine yapılmış olan bu araştırmada, öğrenci merkezli eğitim ekseninde ve temelinde, karma öğretim modelinin, öğrencilerin eleştirel düşünmeleri üzerindeki etkilerine bakılmıştır. Bunun için geliştirilen karma öğretim modeli, üç ayrı öğretim yönteminin en iyi yönleri uygun bir şekilde birleştirilerek oluşturulmuştur. $\mathrm{Bu}$ amaçla yapılmış olan araştırmadan CCTDI vasıtasıyla toplanan verilerin sonuçları ve muhtemel sebepleriyle birlikte etkilerini içeren yorumları, devam eden bölümde sunulmuştur.

Deney ve kontrol grubuna deneysel uygulamaya başlamadan önce ön test olarak uygulanan CCTDI ölçeği toplam puanları karşılaştırıldığında, iki grubun puanları arasında anlamlı bir farklılık bulunmamıştır. CCTDI'nın alt ölçekleri boyutunda da değerlendirildiğinde, hiçbir alt boyutta anlamlı farklılığın oluşmadığı anlaşılmaktadır. $\mathrm{Bu}$ bulgu araştırmada grupların birbirine eşit olduğunu göstermesi bak1mından önemli bir bulgudur. Deney grubuna deneysel uygulama öncesi 
ve sonrası, ön test ve son test olarak uygulanan CCTDI toplam puanları karşılaştırıldığında, grubun ilgili puanları arasında son test lehine anlamlı farklılık bulunmuştur. CCTDI'nın altı alt ölçeğinden olan analitiklik ve meraklılık alt ölçekleri kendi içinde değerlendirildiği zaman, ön test ve son test puanları arasında anlamlı bir farklılık bulunmazken, kendine güven alt ölçeğinde negatif yönde bir anlamlı farklılık oluşmuştur. Açık fikirlilik, doğruyu arama ve sistematiklik alt ölçeklerinde ise pozitif yönde bir anlamlı farklılık bulunmuştur.

Özellikle kendine güven alt ölçeğinde ön test lehine farklılığın oluşması oldukça düşündürücüdür. Türnüklü ve Yeşildere (2005)'nin matematik öğretmen adaylarının eleştirel düşünme eğilim ve becerilerini belirlemek amacıyla kullandığg CCTDI ölçeğinin kendine güven alt boyutunda öğrencilerin eleştirel düşünme eğilimlerinin düşük çıkması da buradaki sonuçla kısmen örtüşmektedir. Bunun birkaç şekilde yorumu yapılabilir. Birincisi kullanılan yöntem ve teknikler öğrencilerin kendine güven duygularının azalmasına neden olmuş olabilir. İkincisi öğreticinin tutum ve davranışları, öğrencilerin kendine güven duygularını olumsuz yönde etkilemiş olabilir. Üçüncüsü öğrencilerin ölçeği doldururken gereğince samimi olmamaları bu sonucu vermiş olabilir. Dördüncüsü ve en önemlisi ise, öğrenciler ölçeği ilk doldurduklarında olması gerekeni düşünerek veya kendilerinde olmayan bazı özellikleri de değerlendirerek doldurmuş olmaları ön testte sonucun yüksek çıkmasına sebep olurken, uygulamanın sonunda ise, kendilerini daha iyi tanıyarak veya olması gereken yerine mevcut olanı düşünerek ölçeği doldurmuş olmaları, sonucun bu şekilde olmasında etkili olmuş olabi- 
lir. Ancak bütün ihtimallerde de kendine güven alt ölçeğinde, diğer alt ölçeklere göre öğrencilerin durumlarında farklı bir değişiklik olma ihtimali daha yüksektir. Çünkü başka bir bakış açısından düşünüldügünde, kendine güven alt boyutu için geçerli olan ihtimal veya varsayımların hepsinin diğer alt boyutlar için de geçerli olması ve aynı oranda onları da etkilemesi beklenirdi. Ancak sadece kendine güven alt boyutunda negatif bir değişimin olması oldukça düşündürücüdür.

CCTDI kendine güven alt ölçeğinde öğrencilerin eğilimlerinde negatif yönde anlamlı bir değişikliğin olması, düşündürücü bir sonuçtur. Çünkü öğrenci merkezli karma öğretimin bu sonucun tam aksine, öğrencilerde özellikle kendine güven boyutunda gelişme sağlamasının ihtimali daha yüksek görünmektedir. Zira öğrenci merkezli eğitimin ilke ve kuralları, geleneksel eğitimle kıyaslandığı zaman, öğrencilerin kendine güven konusunda daha fazla gelişme göstermesi gerekirdi. Öğrenci merkezli eğitimin özellikle, öğrencilerin kendi öğrenme sorumluluklarını almalarını gerekli kılması, ders ortamında ve dersin düzenlenmesinde öğrencilerin görüşlerinin dikkate alınması ve hatta bütün sürecin öğrencilerin özellikleri doğrultusunda hazırlanması gibi özelliklerinden dolayı öğrencilerin kendine güven noktasında daha fazla gelişme göstermesi beklenirdi.

Araştırmanın sonuçları deney grubunda bulunan öğrencilerin eleştirel düşünme eğilimlerinin deneysel uygulama sonrası arttığını göstermektedir. Bu durumda öğrenci merkezli karma öğretim yönteminin öğrencilerin eleştirel düşünme eğilimlerini geliştirdiği söylenebilir. Eleştirel düşünme becerisi ve eğilimi üst düzey bir zihinsel bece- 
ridir. $\mathrm{Bu}$ beceriyi geleneksel öğretim yöntemleriyle kazandırmak oldukça zor, bazen de imkânsızdır. Bu yüzden öğrenme-öğretme ortamının öğrenci merkezli, öğrenciye sorumluluk veren ve aktif olmasını zorunlu kılan, zihinsel olarak sürece katılmasını ve süreç boyunca diğer insanlarla ve öğrencilerle etkileşim içinde olmasını gerektiren yöntem ve tekniklerin kullanılması gerekmektedir. Passmore (1991)'un da belirttiği gibi, eleştirel düşünme becerisini kazandırma aslında oldukça zordur. Bu zorlukların okuldan, öğretmenden, sistemden, öğrenciden veya aileden kaynaklanan birçok sebebi olabileceği gibi, aslında en önemli sebeplerinden birisi aile ve öğretmendir. İlk olarak ailede aldığ 1 eğitim ve yakın çevresinde bulunan insanların, bireye karşı tutumları fazla korumacı ve bütün isteklerini anında yerine getirmek şeklinde, ya da birçok şeyi onun yerine yapmak gibi ise, bireyin kendini geliştirmesi, sorumluluk alması, karar vermesi vb. zihinsel etkinlikleri de yapması engellenmiş ya da zayıflatılmış olmaktadır. Bu tür yetenekler ise, eleştirel düşünme becerilerinin temellerini oluşturur.

İkinci olarak, öğretmenden kaynaklanan yetersizlikler veya eleştirel olmayı engelleyici tutum ve davranışlar, eleştirel düşünme becerisinin kazanılmasının önündeki en büyük engellerdir. Öğretmenin sınıfta aldığı kararları kesin bir şekilde uygulaması, hiçbir şekilde eleştirilmesine izin vermemesi, ders işleme yöntemi konusunda eleştirilere kapalı olması, öğrencilerin ders konusundaki düşüncelerini alma konusunda çekingen davranması gibi davranışlar sınıf ortamında eleştirel düşünme becerisinin gelişimini engelleyen öğretmenle ilgili önemli sebeplerden bazılarıdır. Araştırmada böyle bir alt amaç ve boyut 
olmadığından dolayı, bu iki sebebin de eleştirel düşünme becerisinin etkisini test etme ihtimali görülmemektedir. Konuyla ilgili alan yazında da, öğretmelerin, öğrencilerin eleştirel düşünme becerilerinin gelişimi üzerindeki etkisini tespit etmiş olan bir araştırmaya rastlanmamıştır.

Kontrol grubuna deney grubuyla eş zamanlı olarak ders öncesinde ve sonrasında, ön test ve son test olarak uygulanan CCTDI toplam puanları karşılaştırıldığında, grubun ilgili puanları arasında anlamlı farklılık bulunmamıştır. CCTDI'nın altı alt ölçeğiyle ilgili sonuçlar bağımsız olarak değerlendirildiği zaman, alt ölçekler boyutunda da anlamlı farklılığın oluşmadığı görülmektedir. Aslında kontrol grubunda bulunan öğrencilerin ön test ve son test eleştirel düşünme becerisi puanlarının arasında anlamlı bir farklılığın bulunmaması beklenen bir sonuçtur. Çünkü geleneksel yöntemlerle ve öğretmenin kontrolünde işlenen derslerin eleştirel düşünme becerisinin yanında, üst düzey zihinsel becerileri geliştirme konusunda oldukça yetersiz olduğu bilinen ve araştırmalarla ispatlanan bir konudur.

Deney ve kontrol grubuna deneysel uygulama sonrası son test olarak uygulanan CCTDI ölçeği toplam puanları karşılaştırıldığında, iki grubun puanları arasında anlamlı bir farklılık bulunmamıştır. CCTDI'nın alt ölçekleri boyutunda sonuçlar değerlendirildiği zaman analitiklik, açık fikirlilik, meraklılık ve kendine güven alt ölçeklerinde anlamlı farklılık oluşmazken, doğruyu arama ve sistematiklik alt ölçeklerinde deney grubunun lehine anlamlı farklılığın oluştuğu anlaş1lmaktadır. 
Potts (1994)'a göre eleştirel düşünmenin öğretilmesinde kullanılacak yöntemlerin ve öğretim materyallerinin, öğrencilerde farkl1lık oluşturmaya yarayacak, onları aktif kılacak ve etkin bir şekilde zihinsel olarak kendilerini zorlamalarına yardımcı olacak yöntem ve materyallerin seçilmesi gerekmektedir. Bu özelliklere uygun olarak düşünülen öğrenci merkezli eğitime dayalı yöntem ve tekniklerin de eleştirel düşünme becerilerini artırdığ 1 bu araştırmayla ortaya konmuştur. Konuyla ilgili “Kritik Düşünmenin Mikro Öğretim Dersinde Eleştiri Becerisini Geliştirmeye Etkisi”ni inceleyen Semerci (1999); derslerde kullanılan yöntemlerin ve öğretmenlerin yardımıyla, uygun ortam hazırlandığında eleştirel düşünmenin öğretilebileceğini, öğrencilerin, istenilen niteliklerde eleştiri yapabilecek duruma geldiklerini ifade etmektedir. "İlköğretim Dördüncü ve Beşinci Sınıf Öğrencilerinin Sosyal Bilgiler Derslerinde Eleştirel Düşünme Düzeylerinin Çeşitli Değişkenler Açısından İncelenmesi” isimli çalışmasında Demir (2006) ise; ilköğretim okullarının dördüncü ve beşinci sınıflarında öğrenim gören öğrencilerin sosyal bilgiler derslerinde eleştirel düşünme düzeylerinin öğrencilerin sınıfı, cinsiyeti, öğretmen cinsiyeti, okul türü, sınıf mevcudu, uygulanan sosyal bilgiler öğretim programı, öğrencilerin sosyal bilgiler derslerindeki başarı durumları ve sınıf öğretmenlerinin davranışlarının demokratiklik düzeyi değişkenlerine göre öğrencilerin eleştirel düşünme düzeylerinin anlamlı derecede farklılaştığını tespit etmiş olmaları buradaki sonuçları desteklemektedir.

Deney ve kontrol grubunun son test eleştirel düşünme becerisi puanları arasında toplamda değerlendirildiğinde anlamlı fark çıkma- 
ması düşünülmesi gereken bir sonuçtur. Her iki grubun da ilgili ölçekteki puan ortalamaları incelendiğinde, bir artış gözlendiği ve deney grubunun daha yüksek oranda arttığı anlaşılmaktadır. Ancak bu artış iki grup arasında istatistikî açıdan fark oluşturacak kadar değildir. $\mathrm{Bu}$ durumda geleneksel öğretim ve öğrenci merkezli karma öğretimin öğrencilerin eleştirel düşünme becerilerini geliştirmede etkili olduğu, hatta öğrenci merkezli karma öğretim yönteminin, ilgili konuda geleneksel yönteme göre daha başarılı olduğu söylenebilir.

Ancak öğrenci merkezli karma öğretime dayalı uygulamanın, geleneksel yöntemden anlamlı derecede yüksek çıkmamasının sebepleri aşağıdaki şekilde düşünülebilir. Öğrenci merkezli karma öğretim yönteminin deney grubunda bulunan öğrenciler üzerinde eleştirel düşünme becerilerini geliştirme boyutunda oldukça etkili olduğu, hatta ön test ile son test CCTDI puanları arasında son test lehine anlamlı farkl1l1k oluştuğu daha önce belirtilmişti. Kontrol grubunda uygulanan geleneksel yöntemlerin de eleştirel düşünme becerisini geliştirmede etkili olduğu ancak, bunun ön test ve son test CCTDI puanları arasında anlamlı farklılık oluşturacak kadar olmadığı ikinci alt amaç ikinci denenceye ilişkin bulgulardan anlaşılmaktadır. Bu noktadan düşünülecek olursa yapılacak tek bir yorum kalmaktadır. O da, normalde öğrenci merkezli karma öğretim yöntemi deney grubunda bulunan öğrencilerin eleştirel düşünce becerilerini artırmaktadır. Bu gelişme, grubun kendi içerisinde ön test-son test boyutunda anlamlı farklılık oluşturmaktadır. Ancak, geleneksel yöntemin de eleştirel düşünme becerisini geliştirmesinden dolayı, son test CCTDI puanları karşılaştırıldığında iki grup 
arasında anlamlı farklılık ortaya çıkmamaktadır. Diğer bir ifade ile, bu durum öğrenci merkezli karma öğretim yönetiminin eleştirel düşünme becerisini artırmadığından değil de, geleneksel yöntemin de eleştirel düşünme becerisini bir miktar artırmasından kaynaklanmaktadır. Böyle olsa bile, normal durumlarda ve gerekleri yerine getirildiği takdirde, öğrenci merkezli karma öğretim yönteminin öğrencilerin eleştirel düşünme becerisini geliştirme konusunda, geleneksel yöntemlere, kıyasla anlamlı derecede üstün çıkması beklenirdi.

Öğrenci merkezli karma öğretim yönteminin deney grubunda bulunan öğrenciler üzerinde eleştirel düşünme becerilerini geliştirme boyutunda oldukça etkili olduğu, hatta ön test ile son test CCTDI puanları arasında son test lehine anlamlı farklılık oluştuğu daha önce belirtilmişti. Kontrol grubunda uygulanan geleneksel yöntemlerin de eleştirel düşünme becerisini geliştirmede etkili olduğu ancak, bunun ön test ve son test CCTDI puanları arasında anlamlı farklılık oluşturacak kadar olmadığı ikinci alt amaç ikinci denenceye ilişkin bulgulardan anlaşılmaktadır. Bu noktadan düşünülecek olursa yapılacak tek bir yorum kalmaktadır. $\mathrm{O}$ da, normalde öğrenci merkezli karma öğretim yöntemi deney grubunda bulunan öğrencilerin eleştirel düşünce becerilerini artırmaktadır. Bu gelişme, grubun kendi içerisinde ön test-son test boyutunda anlamlı farklılık oluşturmaktadır. Ancak, geleneksel yöntemin de eleştirel düşünme becerisini geliştirmesinden dolayı, son test CCTDI puanları karşılaştırıldığında iki grup arasında anlamlı farklılık ortaya çıkmamaktadır. Diğer bir ifade ile bu durum öğrenci merkezli karma öğretim yönetiminin eleştirel düşünme becerisini ar- 
tırmadığından değil de, geleneksel yöntemin de eleştirel düşünme becerisini bir miktar artırmasından kaynaklanmaktadır. Ancak böyle olsa bile, normal durumlarda ve gerekleri yerine getirildiği takdirde, öğrenci merkezli karma öğretim yönteminin öğrencilerin eleştirel düşünme becerisini geliştirme konusunda, geleneksel yöntemlere kıyasla anlamlı derecede üstün çıkması beklenirdi.

\section{Öneriler}

Araştırmanın önerileri iki başlık altında verilmektedir. Bunlardan birisi araştırmada ulaşılan sonuçlara bağlı olarak geliştirilen öneriler, ikincisi ise benzer bir konuda yapılacak farklı bir araştırma için diğer araştırmacıların yapması gerekenlerle ilgili önerilerdir.

1. Dersleri tek bir yöntemle işlemek yerine, farkl1, birbirini tamamlayan ve destekleyen yöntemlerin birlikte kullanılması, öğrencilerin hem dikkatlerinin sürekli olmasında hem de derse daha istekli olarak katılmalarına sebep olmaktadır. Bu yüzden derslerde uygun yöntem ve tekniklerden yararlanmak ve gerekiyorsa bunları aynı ders için birleştirerek kullanmak etkili olabilir

2. Öğrenciler yeni ve farklı, aynı zamanda öğrenme sorumluluğunu önemli ölçüde kendi üzerlerine yükleyen yöntem ve tekniklere karşı tepkili ve isteksizdirler. Bu tür yöntemlerin faydalı olmayacağını veya kendilerine ve sınıflarına uygun olmadığını düşünmektedirler. $\mathrm{Bu}$ mazeretlerin çoğu da, alışkanlıklarını değiştirmeleri gerektiğinden kaynaklanmaktadır. Bunun için, geleneksel olarak kullanılagelen, bilinmiş ve alışılmış yöntem 
ve tekniklerin yerine, farklı ve öğrenci merkezli yöntem ve tekniklerin öğretim kurumları tarafından tercih edilmesi ve kullanılmaya başlanması önemlidir.

3. Öğrenci merkezli öğretim yöntemlerine dayalı olarak işlenen bir dersin, geleneksel yöntemlerle işlenen bir derse oranla eleştirel düşünme becerisini geliştirmede daha başarılı olduğu görülmüştür. Bu bakımdan, öğrenci merkezli yöntem ve tekniklerin dersler için önemli katkıları olabilir.

4. Öğrenci merkezli eğitimden ya da öğretmenden kaynaklandığı düşünülen ve öğrencilerde kendine güven olgusunun zayıflamasına sebep olan bir sonuç bulunmaktadır. Bu nedenle öğrenci merkezli eğitim uygulamaları da dâhil olmak üzere her türlü eğitim-öğretim uygulamasında, özellikle öğrencilerde kendine güven duygularını geliştirmeye yönelik çalışmalar yapılmalıdır.

5. Geleneksel yöntem ve tekniklerle yapılan eğitim-öğretimin öğrenci merkezli öğretim yöntem ve teknikleri kullanılarak yapılan eğitim-öğretime göre daha az başarılı olduğu bulunmuştur. $\mathrm{Bu}$ nedenle eğitim-öğretim için geleneksel öğretim yöntemleri haricinde bir alternatifin bulunmadığı durumlarda, en azından farklı birkaç yöntemin birleştirilmesiyle daha etkili bir öğretim yapılabilir.

6. Karma öğretim modeli olarak kullanılmak üzere geliştirilen modelin, öğrencilerin analitiklik ve meraklılık alt boyutlarında öğrencilerin eleştirel düşünme becerilerini anlamlı derecede geliştirmede yetersiz kaldığı ortaya çıkmıştır. Bu nedenle ge- 
liştirilecek farklı karma öğretim modellerinde öğrencilerin bu yönlerinin geliştirilmesi için uygun yöntemler seçilmelidir.

\section{Kaynakça}

Açıkgöz, K. Ü. (2005). Aktif öğrenme (7. bask1). İzmir: Eğitim Dünyası Yayınları.

Atlas, D. (2006). Critical Thinking as Problem Solving. Teaching Learning Committe.

Aybek, B. (2007). Eleştirel düşünmenin öğretiminde öğretmenin rolü. Üniversite ve Toplum, 7(2). Kasım 2007, http://www.universitetoplum.Org/text.php3?id=322.

Aycock, A. ,Garnham, C. \& Kaleta, R. (20 Mart 2002). Lessons learned from the hybrid course project. Teaching with Technology Today, Learning Technology Center, University of Wisconsin-Milwaukee, 8(6). A ğustos 2007, http://www.uwsa.edu/ttt/articles/garnham2.htm.

Clark, D. (2006). Blended learning, an epic white paper. Ağustos 2007, http://www.epic.co.uk/content/aboutus/downloads/Epic_White_ Paper_Blended_Learning.pdf.

Demirel, Ö. (2003). Öğretimde planlama ve değerlendirme-ögrretme sanatı (6.baskı). Ankara: Pegem A Yayıncılık.

Dewey, J. (2007). How we think. Ağustos 2007, http://user www.service. emory.edu/ pthoma4/Dewey.

Erbil, O. (2003). Öğrenci merkezli ĕgitim uygulama modeli. Ankara: Milli Eğitim Basımevi.

Ertürk, S. (1972). Eğitimde program geliştirme. Ankara: Yelkentepe Yayınları. 
Gottlieb, S. (2005). İnnovative assessment in competency based student centered learning. Pedagoji Bölümlerine Yönelik Öğrenci Merkezli Öğretim Semineri, Mesleki ve Teknik Eğitimin Moderni-

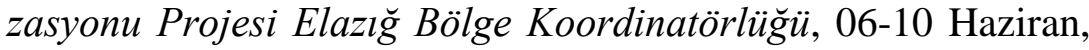
Elazığ: Firat Üniversitesi.

Ingleton, C., Kiley, M., Cannon, R. ve Rogers, T. (2005). Leap into... student-centered learning. Centre For Learning and Professional Development, The University of Adelaide, Kasim 2007, http://www.adelaide.edu.au/clpd/resources/leap/leapinto/Student CentredLearning.pdf.

Kapp, K. M. ve McKeague, C. (2002). Blended learning for comlpiance training success. Ağustos 2007, http://www.astd.org/NR/rdonlyres/CAEE94BB-CCDD-463F-A 9BAC799398DE4A2/0/blendedlearning.pdf.

KAYNAK, (Temmuz-Aralık 2004). Öğrenme kültürü ve karma öğrenme. Kasim 2007, http://www.baltas-baltas.com/kaynakdergiyazi.asp?PRI=313\&S $\mathrm{AYI}=20$

KAYNAK, (2006). Karma öğrenme. Kasım 2007, http://www.baltas-baltas.com/kaynakdergiyazi.asp?PRI=313\&S $\mathrm{AYI}=20$

Kaynar, D. (2007). Blended learning (karma öğrenme)'de yaklaşımlar ve modeller. Kasim 2007, www.buelc.boun.edu.tr/ebulten/sayi09/makaleler/blended_learni ngde_yaklasimlar_ve_modeller.ht

Kökdemir, D. (2003). Belirsizlik durumlarında karar verme ve problem çözme. Yayınlanmamış doktora tezi, Ankara Üniversitesi Sosyal Bilimler Enstitüsü. 
McKendree, J., Small, C. ve Stenning, K. (2002). Kritik düşünmenin öğretimi ve öğreniminde temsil'in rolü. Educational Review, 54(1). Kasim 2007, http://www.matematikegt.gazi.edu.tr/mat/gelisme.

Morin, E. (2003). Geleceğin eğitimi için gerekli yedi bilgi. (H. Dilli, Çev.). İstanbul: İstanbul Bilgi Üniversitesi Yayınları.

ODP, (2003). Strategy for blended learning. Ağustos 2007, http://www.ojp.usdoj.gov/odp/blendedlearning/pdfs/bls.pdf.

O’Neill, G. ve McMohan, T. (2005). Student-Centered Learning: What does it mean for students and lecturers? Kasim 2007, http://www.aishe.org/readings/2005-1.

Oliver, M. ve Trigwel, K. (2005). Can blended learning be redeemed? e-Learning, 2(1), Ağustos 2007, http://www.wwwords.co.uk/pdf/viewpdf.asp?j=elea\&vol=2\&iss ue $=1 \&$ year=2005\&article=3_Oliver_ELEA_2_1_web\&id=78.1 62.232.49.

Öncül, R. (2000). Eğitim ve eğitim bilimleri sözlüğü. Ankara: Milli Eğitim Bakanlığı Yayınları.

Özdemir, S. M. (2005). Üniversite öğrencilerinin eleştirel düşünme becerilerinin çeşitli değişkenler açısından değerlendirilmesi. Gazi Üniversitesi Türk Eğitim Bilimleri Dergisi, 3(3).

Passmore, J. (1991). Eleştirel olmayı öğrenme üstüne, (H. Ünder, Çev.). Eğitim Bilimleri Fakültesi Dergisi, 24(2).

Paul, R. ve Elder, L. (2007). Eleştirel düşünme kılavuzu, (M. B. Fidan, Çev.). Kasım 2007, http://www.criticalthinking.org/files/Turkish_CT_Concepts_To ols.pdf 
Prawat, R. S. (1992). Teacher's belief about teaching and learning: A constructvist perspective. Teachers and Teaching, 11(4), 359-378. Kasim 2007, http://links.jstor.org/sici?sici=0195-6744\%28199205\%29100\%3 A3\%3C354\%3ATBATAL\%3E2.0.CO\%3B2-L\&size=LARGE \&origin=JSTOR-enlargePage.

Singh, H.ve Reed, C. (2001). A white paper: Achieving success with blended learning. ASTD State of the Industry Report, American Society for Training \& Development. Kasim 2007, http://www.centra.com/ download/ whitepapers/ blendeded learning. pdf.

Sönmez, V. (2005). Program geliştirmede ögretmen el kitabı (12. baskı). Ankara: Anı Yayıncılık.

TBV. (2003). Uzaktan ĕgitim kılavuzu. Kasım 2007, www.tbv.org.tr.

Titiz, M. T. (1999). Ezbersiz ĕgitim yol haritası. Ankara: Beyaz Yayınları.

Türnüklü, E. B. ve Yeşildere, S. (2005). Türkiye'den bir profil: 11-13 yaş grubu matematik öğretmen adaylarının eleştirel düşünme eğilimi ve becerileri. Ankara Üniversitesi Ĕ̈itim Bilimleri Fakültesi Dergisi, 38(2).

Ünal, D. P. (2007). Harmanlanmış - karma öğrenme ortamları. Kasım 2007 , http://egitek.meb.gov.tr/EgitekHaber/EgitekHaber/s76/yazarlar/ D\%C4\%B1lsad.htm.

Ünsal, H. (2006). Yeni bir öğrenme yaklaşımı: harmanlanmış/karma (blended) ögrenme. VII. Ulusal Fen Bilimleri ve Matematik Eğitimi Kongresi, 7-9 Eylül 2006. Gazi Üniversitesi Gazi Eğitim Fakültesi. 
Varış, F. (1988). Eğitimde program geliştirme teori ve teknikleri. Ankara: Ankara Üniversitesi Eğitim Fakültesi Yayınları.

Yavuz, K. E. (2005). Yeniden yapılanan sınıflar için aktif öğrenme yöntemleri. Ankara: Ceceli Yayınları. 